\title{
Identity Building of Indonesian Legal Education (From Progressive Liberalism to Transgressive Religious Cosmic)
}

\author{
Anthon F. Susanto \\ Pasundan University, Indonesia \\ http://dx.doi.org/10.18415/ijmmu.v8i2.2448
}

\begin{abstract}
Legal Education naturally is education of human and humanity viewing man in his "earthly existence" to appreciate his human nature or will make the humanity humane as such the vital relation is that world will be more humane, managed and maintain according to the relation between he himself and the creator. Legal education encourages man to understand dan be able to interact with reality of the world surrounding; legal education, therefore, should be able to develop human soul, in this case, is the entire creativity, passion and creation. Legal education is closely related to the development of morality of the law enforcement to be able to improve the performance and professional skill in the law enforcement. To support the concept, legal education should always improve the quality of human's life. Method used was multi-method such as philosophical method using hermeneutic-deconstructive approach; conceptual approach by developing creative ideas through heuristic analysis; method of critique on text to see the new possibilities that can raise in the development made. Philosophical approach can help us to enter into the most essential/fundamental area of the issue developed. Transgressive legal education is human education in the context of Indonesia with the soul of Pancasila. Transgressive legal education is an education to develop moral or conscious to underline the enforcement of the law upon society so that man will aware of the existence of the creator and is able to encourage the development of persons to be critical, tolerant, open, sensitive, and care towards the social problems and law enforcement.
\end{abstract}

Keywords: Legal Education; Transgressive; Human Education

\section{Introduction}

Legal education has been one of the main issues since mentioned by Mochtar Kusumaatmadja (1986), that at the beginning of independence, legal education was merely a training to memorize statutes (textual) as a necessary for the job market. Consequently, the graduates were only labors of law. Along the emerge of new understanding, gradually legal education shifted to focus on the benefit for the society. The education, therefore, developed to have a clear orientation. The 1993 curriculum, for example, was formulated to fix the course and purpose of the legal education by providing standards and guidelines (Mochtar Kusumaatmadja, 1994). Legal education that are able to adjust to the changes at the time. Has 
the spirit and aims been realized today? Parts of the purpose has already been achieved but other parts are still an on-going process. However, the ultimate essence of education still needs more attention.

To what course is the Indonesian legal education is heading after these 50 years? Entering the 21th century, the second century of the paradigm shifting that was mentioned by Reinald Khasali as disruptive (Rhenald Khasali, 2017, p. 301). Is there the blue print or model that can be held on to? What contribution that legal education provides to response to an acute legal and social problem? Is the education directly correlated with the (quality) of law enforcement? Is legal education freeing and educating? Is legal education adaptive to the changes? Does legal education has sensitivity towards the environment? Is this and that? In short, should legal education responsible for all above problems?

Since rationalism firstly introduced by Descartes (modern philosopher), legal education has been strongly influenced by this paradigm. Modern legal knowledge with human reason as the center is the main support of legal positivism that is a school of thought separating moral from law, as the strong influence from the domination in way of thinking of Descartes who was dualistic and reductionist. The segregation of human and nature, where man is treated as the master of the universe has degraded the truth. It is blamed for putting the earth in crisis, the decline of water resources, deforestation, the extinction of thousands of species, the thinning of the air resulting of long-term effect on health. All are the result of uncontrolled human acts. A theologist, Daniel Maguire, urged that if the trend continuous, we will not survive and this is qualitatively new and epochal (Audrey R. Chapman, 20017, p. 21). These all were so accumulated that was causing permanent damage (Audrey R. Chapman, Rodney L. Petersen, Barbara Smith Moran, 2007), therefore the life in the future (is predicted) earth is unworthy (David Wallace Well, 2019). The theory of Descartes received great deals of criticism and rejection in his later theories, mainly from those who integrated the relation of man, God, and the universe. Among them are Paul Davies (2002, 2006, 2012), Fritjof Capra (2001, 2010) and Gary Zukaf (2003), Bruce Lipton (2019), Greeg Braden (2018) and more others.

From this moment on, we will be in web/internet era generation-5 marked with early artificial intelligence technology (Ian Parson, 2018,p.xiv-xv). Changes of behavior, culture, the work pattern of organization/company/bureaucrat are other phases explaining that the change cannot be understood through old paradigm but through the new paradigm (Onno W. Purbo.2003;p.15). The wonderful life of scientific findings and technology (Carl Sagan, 2016) along with the economic development was portrayed dynamically with the emerging of the new power in Asia (Kishore Mahbubani, 2011). All are out of man's control.

Higher learning (University/law faculty) whose unlimited financial source and wide access of power is easy to optimize the advance of technology for the learning; however, most are still in darkness. Some even have no clue about the nature of the change itself. Problems often dealt with by law school who's busy to calculate the ratio of teaching staff, the benefit of the lecturers, almost collapse building, spotlighting accreditation and continuing disputes over the ownership of the university or the school.

There is correlation between legal education and law enforcement. It is said that legal education is the upstream of law enforcement (Judicial Commission, 2012). Outlooking the performance of law enforcement, it is consciously upsetting that every information displayed on media shows the problems of moral and conduct. Law enforcement crisis in Indonesia is due to some factors: dominance of the power in judicial system, economic yearning, and bureaucrat pathology (administration) of judicial service. Education cannot be running well and the nature of education becomes the part of legal system supporting the law enforcement.

Most of the expertise, about 50\%, of law enforcement are molded in university. It can be said that the quality of the graduates with the technical skill possessed can stand in the same line with any skill 
training in Indonesia. Most of the higher learning succeeded to create professional independency for their graduates. However, it can be the pitfall of the law enforcement in Indonesia. Is it because it so focuses on the development of skill that the aspect of moral and conduct is abandoned? Might law school be a culprit of the moral crisis? Moral crisis occurred when rapid changes are not balanced with the ability to adapt and modify. A gap between the advance of technology and affordability; the development of science and the life necessities, and many more is created. This moral crisis can generate crisis on trust, authority, economy and also law. People do not trust law and its law enforcement. Moral crisis, naturally, creates various crisis in a domino effect way. It flows and end up in identity crisis. It is the most severe crisis of the century of which, moral crisis generates "mass delusion" in law enforcement which Simon Blackburn called as false consciousness (Simon Blackburn, 2004, p. 50-51). Law enforcement operates behind mask and plays parody to cover the truth and justice.

Legal education policy in Indonesia, can be seen gradually by, for example, paying attention to the ideal goals stated in the National Education Act: educating the life of people including to fix morality and behavior. This policy, later on, is interpreted into more practical regimes, from implementing regulation to technical circular on how to manage legal education, and even to the curriculum to implement by universities that naturally is not separated from the policy of education in general.

From our understanding, education of moral and conduct is still the homework many universities and law school have to do. Problems with internal of the universities are still not manage sacrificed the morality aspect. Some universities and faculties gradually reduced some of their non-legal subjects and added more lawyering skill training. If there was, the percentage is miniscule and limited. Law school more focuses on dispute settlement technique, case analysis, legal opinion, and legal drafting. Structure of reasoning is more on syllogism, or deductive and inductive logic and legal reasoning and legal construction. Important but it is not enough.

In a large scale, people agree that the best way to improve people's quality is through legal education. The process, however, is not that simple. We may agree with the policy on legal education, but the problem is that some people are against legal education producing (side effect) lawyers or graduates reflective to the life of public (Gregory Leyh, 1992; 2008), something considered uncritical towards the relation between the legal learning and public learning (James O Freedman, 1885, 741). This writing raised some crucial issues such as (1) the position of legal education amid the liberalism and new capitalism; (2) Course and the development of legal education in the relation with Indonesian identity and personality; (3) The construction of transgressive religious cosmic of legal education.

\section{Methodology}

Method used in this writing (1) philosophical method using hermeneutic-deconstructive approach (2) conceptual approach through development of creative ideas with heuristic analysis. (3) critique analysis on text to find any new possibility that can occur in the development. Philosophical approach can help us to enter into the most essential/fundamental of the issue. Philosophy always concern about the nature of thing. In this research, method of philosophy through hermeneutic deconstructive approach analyzed basic ontology of legal education to consider reason/logic behind legal education (Anthon F. Susanto, 2010, p. 120-123). What becomes the idea and hope for the future legal education, and other essential aspects and other intertwining aspects. From the wide range of reference, it then is compiled and interpreted through analysis.

Conceptual method presents relevant doctrines to be integrated, combined into relevant model with targeted purpose. This method, naturally conceptualizes various ideas combined or convergent into the new idea (heuristic method). Critique analysis on text is used as dissecting knife to exam the weakness 
and strength of the concept/model/idea proposed to understand the relation between legal education and law enforcement. Consilience model of three merged approaches and triangulation (Anthon F. Susanto, 2015, p. 213), common leap when the three approaches are used (Anthon F. Susanto, 2007, p. 67; 95), and some other approaches as well.

The approach used is described in below figure:

\section{Figure 1}

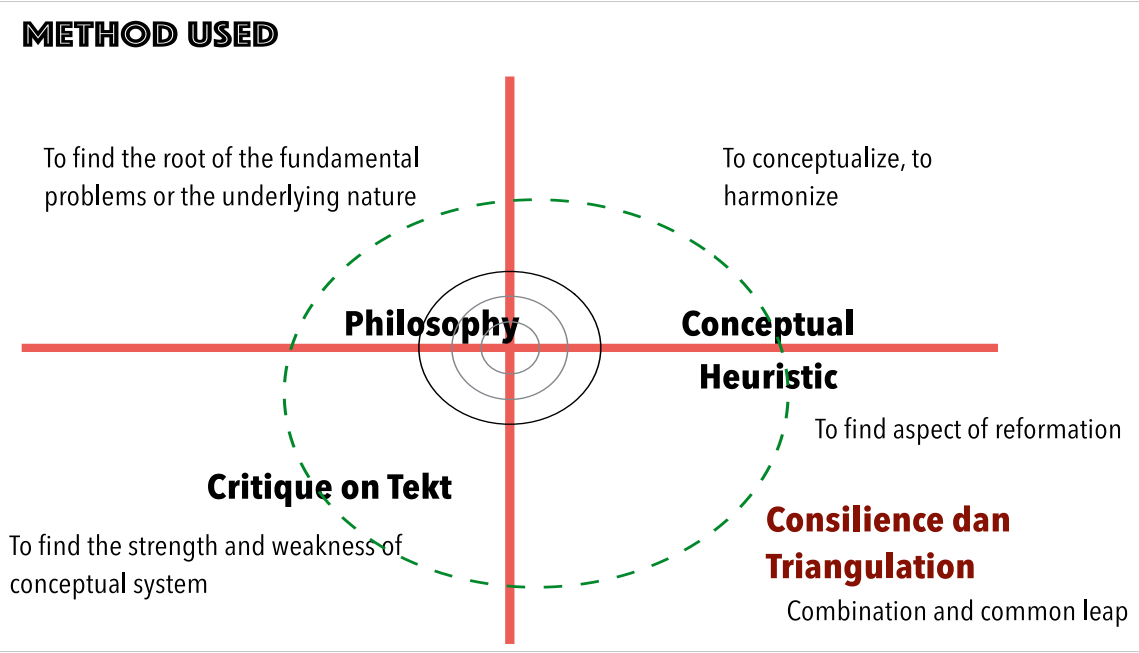

\section{Findings and Discussion}

\subsection{Legal Education amid Contemporary Ideology}

Historically, the mark of changes happened today was predicted long before with regard to history and the spread of ideology that follows global development. Invention on internet, followed by the development of cloud space created people addiction to digital ware or gadget, high-speed computerized system controlled by intelligent robot. It gave hint to what will happen to future education. Dominance of artificial intelligence has entered the field of education including legal education, consequently innovations in education world and incredible acceleration on data presentation/learning materials occurred because everyone can access data easily everywhere: a concept of "Freedom Learning". Deco or digital ecosystem will be a new ecosystem of the world, therefore gadget such as tablet and laptop are two of must have gadgets. It can be claimed, thanks to the hard work of science, that development of education through technology which has not yet accomplished since thousands of year ago has finally achieved. Everything is sophisticated, luxurious, complete and fast.

Addiction to digital technology triggered by the accelerating machines leads to significant changes in method of data finding and the ability to re-compiling. Learners learn more effectively as data are displayed and presented before them by smart machine. This phase explains that education is entering into the life of DECO or digital ecosystem. The space of education is open because everything is inclusive and we are motivated to be ready at all time for silence means death. However, digital world also provides room for new crime, sophisticated crime motive, and other offense (Agus Sudibyo, 2019, p.1-3). This is paradox of reality that technology, on one hand, is highly relied on while on the other hand, all private data are easy target of cybercrime. 
Acceleration is a new machine operating in digital world of fast, efficient and effective. First come first served, those who slow will be left behind. Those with more access to information will survive for in this era, information determines the level of intelligence. McDonald's chain stores developed in the 90s are now the heart of (legal) education system in almost all part of the world. Capitalism and liberalism are reborn inside new package and stronger power. Ideology of competition in education, liberalism, and capitalism develops into new power (Agus Nuryatno, 2008, p. 66-dst). Through globalization (with acceleration machines), neo-capitalism and neoliberalism run down all who tries to fight against.

Higher learning is shifting into business corporates, education inside Malls, education institution owns Mall promoting malls owned by the institution. Some universities openly explained that they were under or sponsored by a business corporation. While, foundation that initially was considered as nonprofit organization, is now becoming an institution managing profit-oriented education. This business corporation succeeded to exploit intelligence by conducting brainwash. Nationalism fades away, people now are easily divided and infiltrated with any ideology. This is a new imperialism when the partition is lifted, all locals become global and the survival ability is determined by how far is our commitment. But in the end, aware or not, all will be crushed down by the new form of capitalism and liberalism. Worse, erosion of moral-spiritual is in all aspects of life. (Mark Slouka, 1999, p. 14).

Human faced their turning point of their spiritual reality that took over the spiritual, religion, and believe. Holy text will be replaced with texts and pictures on Tweeter, Facebook, or Instagram. Believing mystics is then changed to unimaginable game simulation, imaginative superhero, and fantastic pictures. People spends long time on computer to satisfy their passions instead of going to churches. Education will become a ritual game: a game to play the game. The players are each one of use, the agent of change of the giant corporations such as Microsoft, Google, Apple, Samsung, and many others (Jeffry L. Cruikshank 2008. David A. Vise, 2006). When the game is playing on, in the end it creates or forms consciousness of digital universe (Jeff Zaleski, 1999).

People are persuaded with entertainment and luxury. Big-scale economy is mostly run by giant corporation and digital technology, digitalism will become consciousness (Jamie Notter \& Maddie Grant, 2018, p. 9) (Yuswohady, 2019). In this position, optimism is raised, but at the same time life and values on humanity fading away is being a concern. Alec Cross explained (this we can apply to the reality of education) that development of organization or industry in the future is a challenge. The question is whether they can adapt or become extinct (Alec Ros, 2018).

Acceleration is a machine working in this century. Generation $\mathrm{Z}$ and millennials with jargon digitalism spirit of openness, and the believe in flexibility has encouraged massively the used of social media as the main space for interaction. Since the bang of printing machine era in $16^{\text {th }}$ century lifting the spirit to read books and even causing the explosion of publication (Asa Briggs, \& Peter Burke, 2006), a new blast triggered by the spirit of William Gibson in his novel "Neuromancer", that there is no more paper and books and the letter e- (bike, book, shop) is attached to almost everything. Life (reality) is convergent and social media is the new model of life changing all aspects of our life (Nicholas A. Christakis, \& James H. Flower, 2010, p. 19).

The future of Indonesian legal education is not easy to predict; however, it is not impossible if we want to detect the symptoms today. It is possible that future will run for about 30 or 40 more years. But what will happen to the world of education today predicted from the symptoms is that "education is often related to the development and the progress of "education developmentalism" community has created a big illusion as in reality it is not walk side by side. Construction of ideology behind the education often change the course and even break the development chain that should be run parallel with the reality of necessity. This is paradox. On one hand, more and more universities are at world rank in are at high place. 
On the other hand, education seems having no correlation with the effort to fix morality of people especially when related to problems of economy, politics, and social. But does education want or get prescription/remedy as the balancer in the middle of the attack of various ideologies manifest or laten (William F. O’Neil, 2008).

It is described that the asset of education is lessen. The stock of education is now owned by other people, consequently the poor is struggling to get facilities. Educators are buried in their research projects in all forms as such only few are for the sake of the marginal community. Perhaps, it is only about $20 \%$ of the research can be beneficial for the poor. The rests are kept and piled up in library book racks of the universities. The policy on education is a dilemma when the purpose of the regulation is difficult to realize. The education management is facing hyperregulated where many rules are overlapped, corruption committed, tension continues to occur between bureaucrat and politician

\section{2. $\quad$ Education in the Middle of Liberal Law and Positivism}

Liberal law, naturally, is the pulse of today legal education. Almost all law schools, universities, faculties, and higher learning (law) teach liberal legal system as legacy of history and global development. Historically, there were fundamental difference throughout the course of the history of legal education in liberal countries. However, there are similar problems that is multiple personality of legal education. On one hand, law school offers professional training enabling their graduates to carry out their work in the society. On the hand, however, the professional mission always walks side by side with rhetoric that law is liberating study. The two that did not work well. Legal education, on one hand, produces professionals with orientation to fill the job market in the society. Learning process aims to produce graduates with skills and technical expertise (Satjipto Rahardjo, 2009, p. 20), of which are, in general, so bound with rules and regulations that they carry out their profession under the rules that binding. On the other hand, education teaches about freedom rejecting the hegemony of positive law/the regulation.

If we trace to the root of liberal legal education in the West, we can refer to Langdell for the leading actor through his approach in professional in legal study. Langdell applied classic orthodox approach (Thomas Gray,1983p.1) where law as a scientific conception set aside non-legal perspectives discussing law, including sociological, historical, and economic legal phenomenon as developed by his mentor, Hans Kelsen. Classic Orthodoxy is an approach to understand and teach law and the system from within. This teaching was developed in America and changed the curriculum and legal education into professional education in 1900 (Robert B. Steven, 1983, p.39) whose influence are still strong in Indonesia today.

The desire to repair and reform legal education to be more functional and hold a clear identify had been done long before the independence of Indonesia. Paul Scholten, one of scholars concerned about this tried to compile a guideline (in 1924) containing (a) independency, and identity of Indonesia, and (b) its application with the orientation to the needs of Indonesian people itself. However, in fact, the application still follows the education policy of the Dutch with European-Continental type of legal system. The policy is top down since education is centered in Universities and Faculty under the statutebased legal system. This is difference from its counterpart, the common law system that (at that time) was more bottom-up. Legal education in Common Law countries are mostly taught outside the campus, at the professional institutions through internship and externship.

At the next stage, legal education began to breath the new air and was directed to make a new reorientation particularly post-independence era marked with the raise and emerging seminars and study centers in the universities and faculties. The influence of common law system began to sink in, for example the model developed by America of which was marked with graduates from ivy-league 
universities in the United States of America and made it as comparison. It is recorded that Indonesian scholars such as Mochtar Kusumaatmadja, Satjipto Rahardjo, Soerjono Soekanto were graduated from such reputable universities in USA. However, education in Indonesia dominantly direct the skill to apply the positive law (statutes) (Satjipto Rahardjo, 2009, p.28). For this, Satjipto Rahardjo threw a critique that legal education had not yet if not at all been humanity oriented. Even though gradually, in later years, science-based legal education emerged as the complement to practice-oriented education at postgraduate and doctoral level, however the heart of learning process is still under the hegemony of liberal legal system that contains more doctrines in hollowness.

Recently, legal education enters crucial moment that is the co-optation of corporation in education (with the spirit of liberal law). Then, business on education era begins through jargon of globalization and ideology of neo-liberalism and neo-capitalism. Education becomes money machine while university/faculty is the brand name. Higher learning (law) is part of business unit at the foundation level or certain corporation. This is naturally that education is always at the center of power (HAR Tilaar, 2009).

There are three impact from the domination of capitalism over education (1) education practice supports more the economic control and the elite; (2) science merely aims for profit rather that creating better quality of life; (3) the victim is the values of social justice and human dignity (Anthon F Susanto, 2015 , p. 36). Through globalization, corporation, system of capitalism, and liberal individual, legal education became hegemonic over all aspects of social life of society for general principles, norms, doctrines, theories and all are always deconstructed through the Western perception. Global trading cooperation started to enter AFTA, NAFTA, WTO creating "Global Intellectual hegemony".

Legal education under liberal legal system which principally is legal positivism, finally establishing the culture of positivism that is technocratic-rational culture with two main characteristics: conformity and uniformity (M. Agus Nuryatno, 2008). Conformity directs the learners to be passive and adaptive to text (book) and context (reality of life). This is potential to degrade the critical thought. Simple learning process and one without critique and production of knowledge will be linier or one way. The learning of positivism holds characteristic of uniformity that takes part in creating one dimension of human and society.

Positivism-based education with foundation of liberal law is not oriented to the goal of ethichumanity since in this tradition, values and interest should always be separated from law. Consequently, the consciousness aspect of critical historical of people in legal education does not only affect the building of subjectivity of the learners, curriculum designer, learning process, adjudication, and perspective on (legal) knowledge. Even at the end, when they are graduated, they dominate the system of law enforcement. Learning based on positivistic approach with model of rational-positivistic paradigm regards law from limited perspective which is rules and logic. The values only serve the pragmatic-technical interest. Law is deemed as the region of norms that is value-free, objective, and universally valid. Positivistic-based legal education puts educator as know-everything individual while learner is an empty glass.

This problem is because learning process is more of a process of how to possess and accumulate knowledge rather than of how to understand, criticize, produce, and apply the knowledge as the tool to change the reality (Paul Alman, 1998; M. Agus Nuryanto, 2008, p. 60). No doubt that this type of learning model has an investment to degenerate critical subjectivity since legal education is orienting their students to legitimate and strengthen the knowledge and social system without providing critical vision necessary to articulate their voice and to shape their own history and destiny; Positivistic legal education provides contribution in making the reflective critical reasoning needed by man to participate in their social life shallow. Principally, positivistic legal education has indeed encouraged a pretty progressive development generating liberalism and capitalism of the education and making the law enforcement individual, liberal and capital. 


\subsection{Understanding the Philosophical Root of Legal Education}

Naturally, legal education is education on human and humanity. Discussing legal education as education on human, we are entering into the understanding of personalistic human philosophy. That man holds basic structure and what determining the structure are: (Alex Lanur, 2000.p.84). 1. Man as physical-spiritual creature; 2. Man is a creature of social-individual; 3. Man is a free being; 4. Man is historical animal. Meaning that a man at least should include all the above aspects. Legal education should perceive man in its existence, its existence in the earth because world is naturally an extension of human corporal (physical) to comprehend the humanity or to make human humane. Therefore, the essential relation is that the world will be more humanized, processed, managed and maintained according to the relation of itself and the creator. Legal education, then, encourages man to know and able to interact with the reality of the world surrounded; legal education, therefore, should be able to develop the human spirit in a sense that the entire imagination, feeling, creation.

Legal education is related to cultural transformation that culture and education are two vital issue intertwining in order to improve the quality of life. On one side, the development and preservation of culture is taking place in the process of education or requiring educational engineering, while on the other side, education demands the system of culture as the root and support of the existence of the culture. Development of culture requires the freedom of creativity while education needs firmed stability of culture (Baharuddin \& Moh Makin,2011, p. 13). By realizing this, man can aware, understand and love each other and bow in front of God. In this stage, this leads to education model that is expected to be a real humanistic.

When discussing education in stato sentris where state determines every aspect, education will fall down and be indoctrination. Therefore, if education pays attention to the individuality of human, gives room and role to the creativity, talent, and the needs of learners, education will be able to stimulate source, creation, and imagination and their creativity. In other perspective, relation of individual with their surroundings, learners will adapt themselves to the environment and help to develop independent and responsible persons that can encourage novel researches and breakthroughs in law field that has great implication on law enforcement. On its social corner, legal education will be able to encourage learners to communicate with others. This will become a nurturing process for them to able to recognize local law, moral values, unique values so that they will be able to always be positive and, at the same time, critical.

Legal education can encourage its learner to be an individual who can take role, determine, decide, and control upon negative influences. This places legal education no only to train skills and expertise, but also to build characteristic and life skills and encourage learners to be able to embrace their life and to be responsible so that they will not be follower but smart in deciding their choice instead.

Man is flexible in the process of its development either of biological or psychological. In this stage, it is important for learners to identify their national identity, historical background, and of course, the main principles. Legal education will, therefore, holds a clear identity that can be recognized from the ability of learners to creatively guard, preserve, pass on the tradition they inherit. In this part, we have two points of view that is crucial to combine: digital universe intelligence, a body of intelligence that is united and combined by technology. It is a super intelligence that is a combination of men using high speed internet and education of humanity trying to glide inside the identity of the man to rediscover the nature of Indonesia legal education.

\subsection{Transgressive Religious Cosmic in Legal Education}

Crisis of Indonesian education needs a serious attention, particularly in reconstructing the idea of the predecessor of Indonesian education so that it can adapt to the development and utilize it as the power 
to change and to compete at the same time. This option is inside us trying to explore possibilities for the unique and complex spirit and ideas of Indonesia (R.E. Elson, 2009). This idea is not implemented in a romantic-ideological way but rather by showing discourse or narration living in society in Indonesia to rebuild optimism. We all are responsible and naturally, education should be responsible to at least shaping the character of Indonesian. Education should provide solution to so many ideas that should be advocated because naturally, education is essential for the process of humanity in a civilized society.

To emphasize the above mentioned, this writing showcases the more reasonable paradigm on the endeavour to re-construct legal education. A new pathway called Transgressive Religious Cosmic Legal Education is required whose characteristics as follows:

Concept of Transgressive. This concept is used by adopting the doctrine of Gordon Rixon in his book Derrida and the Lonergan on Human Development. The meaning of Transgressive can be articulated as beyond progressive (Anthon F. Susanto, 2019, p.59-62). The concept is adopted and modified from that of Gordon Rixon (Anthon F. Susanto, 2017, p. 21) that is a strategy to reveal the process of interpretation as such it does no longer depend on the original text, but rather is out and beyond the meaning of the text. The concept of transgressive, naturally, was derived from the word transgress meaning a process beyond logic or binding rules. If the concept is adopted in reality of education, logically, it is a paradigmatic way in which legal education should be free from the bondage of liberal model of legal education that is positivistic.

Transgressive concept of education, principally, tries to plant the seeds to understand the values of anti-stagnation so that education in universities and faculties can be the agent of change and benefial for the society. Transgressive concept differs from progressive concept. However, both contains meaning of development process. The word progressive means structured progress or a progress that is based on set structure (Anthon F. Susanto, 2019. P 59-60). Progressive is a gradual development that is on the track of the development therefore the concept of progressive, actually, is a process of development in a controlled process. Progressive means that the progress is not linear but rather accelerative. However, the meaning is the accelerative development is still in a set corridor; a progress that occurs inside a structure or shell covering as illustrated below.

\section{Figure 2}

\section{Progressive and Transgressive}

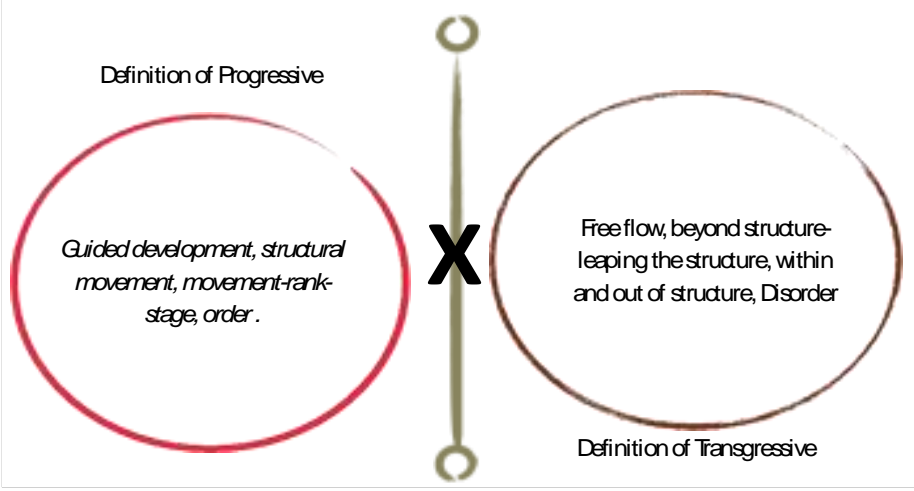




\section{Figure 3}

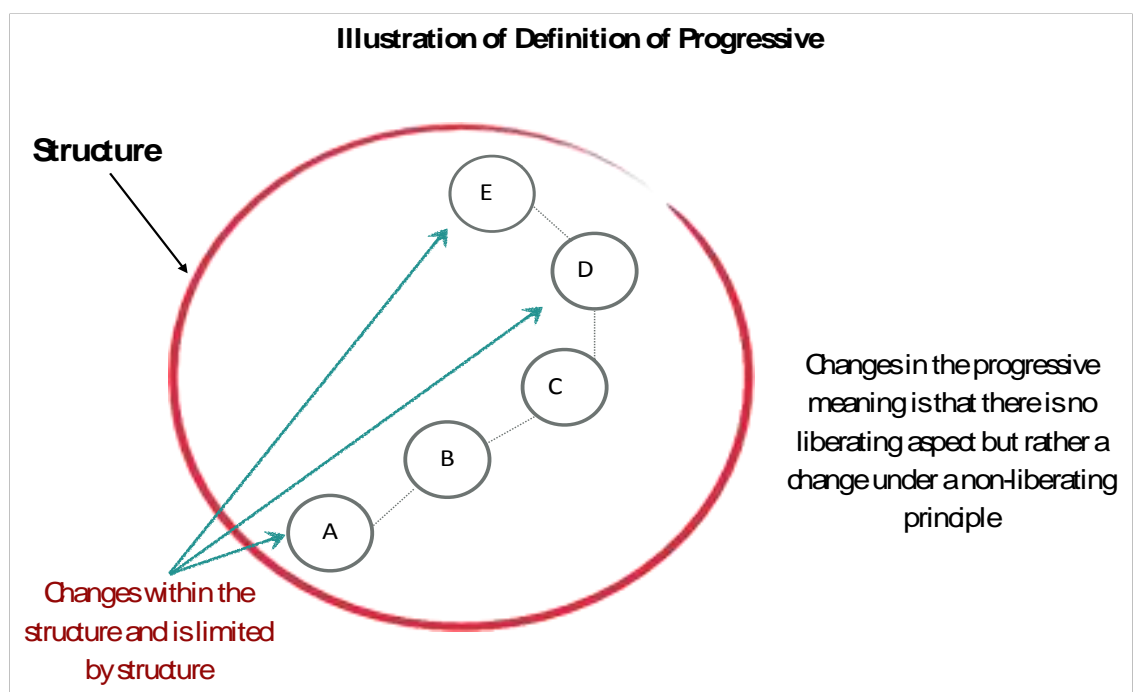

Transgressive concept is different. The development meant here is a bound trying to leap out of the shell or structure that is holding it which then may create the structure cracked. However, the broken structure means that the development is entering a new structure that is different from the old one. Then it creates its own structure or gets out from the old structure to create the new one. If then a confinement occurs by the new structure, the development will again jump out and find the other structure or create a new other one. It goes on and on and process repeats unlimitedly as showed in below figure.

Figure 4

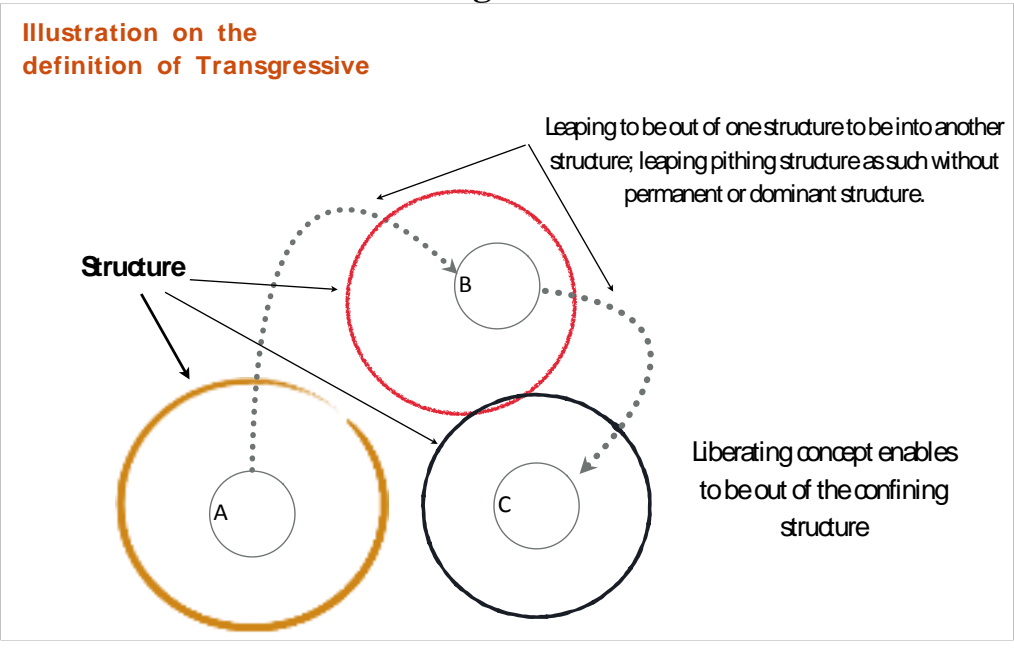

Cosmic Religious. The term religious refers to the concept of a strong religiousness, a bondage between one and his believe, also a tie between one and his ancestry/tradition and the ecosystem or area where he lives. Cosmic, in general, is defined as universe/cosmos. In this part, religion is a relation between man and his creator and the cosmos. Cosmic should be understood as the universe while religious is the relation/bond; the relation of human and the universe/cosmic; interaction generating meaning. The concept of Satjiko Murata on the marriage of the macro cosmic (heaven) and the micro 
cosmic (earth) implemented in the marriage of human, between man and woman, between Yang and Yin is the form showcasing the concept of cosmic religious (Satjiko Murata, 1998.p. 197).

The reality of man's spirit, the awareness bound by the universe. The concept of cosmic religious can be described as the believe of traditional community or local wisdom that later on becomes the guidance and the conduct in their life. Local wisdom always expresses the bond of individual, community with the ecosystem sourrounding; the bound with the Creator that we can still find in the tribal community such as Sunda, Atjeh, Padang, and others. Indeed, this concept specifically refers to the reality or context of Indonesia on the plural awareness, care and sensitivity, the love of the homeland, the value of unity, justice and ultimately the relation to the Creator. These values are manifested in Pancasila as the soul and the idea of the nation of Indonesia.

The bond generates believe. When our behavior is inappropriate, universe will make a restoration to keep the value balanced. This is a relation of cosmic religious. The concept of cosmic religious is the concept of biological, anthropological, ecological and even spiritual concept. Bruce Lipton, a cell biologist discovered an amazing life of cell that gen, cell and organ are always related to the environment; that the cell attentiveness towards environment does determine the mechanism of life (Bruce Lipton, 2019.p. 18). The research developed led him to enter into a new science of life and the nature of humanity; empowering society to control their life and taking part as the creature of harmonious future earth. The same thing was argued by Gregg Braden that the attentiveness played an important role in the existence of universe. Man is an artist and its creation at the same time (Gredd Braden, 2018. p. 11).

This concept was applied in legal education to view the strong relation of how man and his selfness, and man and his creator become the guide in living the life. Morality and ethic become important for us to hold consciousness. This is the main concept that should be established by legal education: human education. Transgressive legal education is human education that is education on conduct; of how man interacts with other human and with his God, and with the environment. This kind of legal education will bring us to some crucial thing. Legal education is a moral-based education that can encourage the students to be sensitive and hold consciousness. The concept of morality in education, no other, is a fundamental concept in which scientific and professional education are parts of some specificity; however, the essence to be build is the academic and professional ability can be guided by morality. The concept of cosmic religious, indeed is the morality of human towards Allah and the environment, as the Prophet Muhammad was the messenger of that "We have sent you forth as nothing but mercy to people of the whole world" (QS. Al-Anbiya:107).

The leap of intelligent. The leap of intelligent underlies the paradigm of transgressive legal education. Legal education of positivism culture is more oriented to the single intelligent that is reason/logic in which ratio become the parameter of the truth of everything on law. The process of reasoning on both text and legal context will be correct if the parameters are rules and logic. The scientific truth in law is measured with rational parameter and can be proved empirically where law at all time is understood as a system of rules where logic is the structure.

In the concept of transgressive legal education, there are other intelligents can be used other that IQ-Intellectual Quotient such as Emotional Intelligence (Daniel Goleman, 1993; 1999) and Spiritual Intelligence (Danah Zohar, Ian Marshall, 2000). If we see what has been developed during these 20 years, the concept of single intelligence called IQ has no longer dominated the model of intelligence in legal education or even the practice of law enforcement. The domination of IQ as the sole intelligence was criticized and denied from its existence considering that man is given so much intelligence inherent inside himself. Man is not merely a rational animal, but rather is a thinking and imaginative one; a creature of race and meaning (Agus Efendi, 2005, p. 3-12). If we take some findings of research done by, for example, Gay Hendrick and Kate Ludemean, or narration conveyed by Bob Galvin, there are other forms 
of intelligence such as spiritual non dogmaties and "the care for others" (Agus Nggermanto, 2015, p. 1314). Howard Gardner suggested that intelligence as what he called multiple intelligence, requires instruments to evaluate the various intelligence in education, not only linguistic and logical intelligence as the dominant parameter today (Howard, Gardner, 2003, p. 26-dst).

Long before Descartes argued "cogito Ergo sum" (I am thinking, therefore I am) to hypnotize the world, Prophet Muhammad SAW had already suggested the center of existence to determine the quality of selfness of man that is "Qalbu". Qalbu means a source of spiritual consciousness and equals to consciousness. With qalbu, man is able to think, understand, comprehend, and determine which is good and bad. This potential intelligence is called prophetic intelligence (Hamdani Bakran Adz-Dzakiey, 2005, p. xiii).

What defined as transgressive concept of intelligence is none other than to integrate the concept of all intelligences: IQ, EQ, SQ which Boobi DePorter called as quantum intelligence which every single person actually possesses brain potentially as big as Einstein's. It is up to how we manage it. The transgressive concept tries to go beyond that by making a leap to combine the intelligence of human as a whole with the intelligence of the universe that is super intelligence such as intelligence possessed by every individual integrated through high speed internet. This can be seen in below figure.

\section{Figure 5}

\section{Modification of IESAQIntelligenœ in Transgressive legal education}

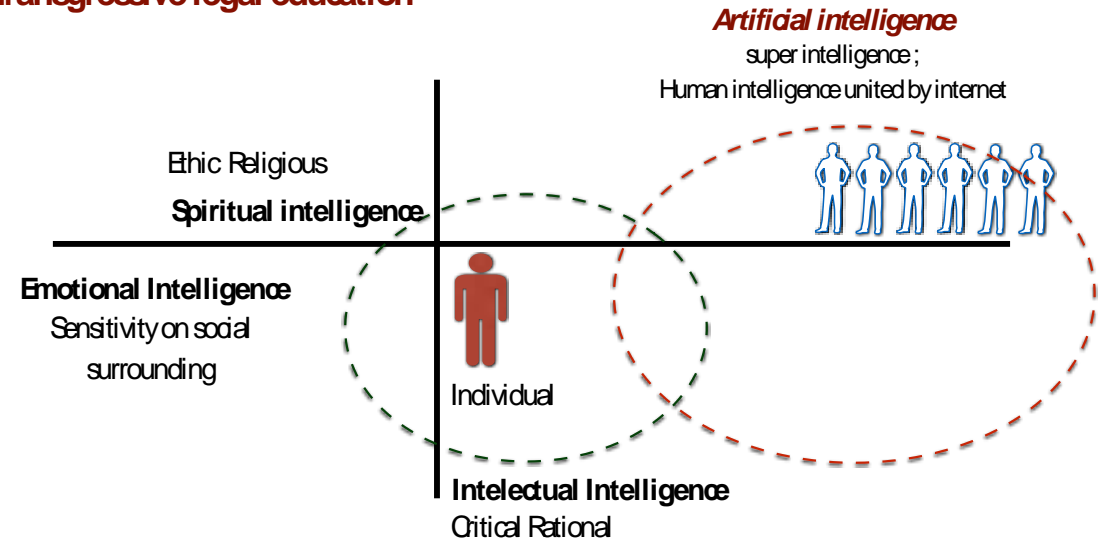


In a more detail legal education, it can be seen as follows:

Figure 6

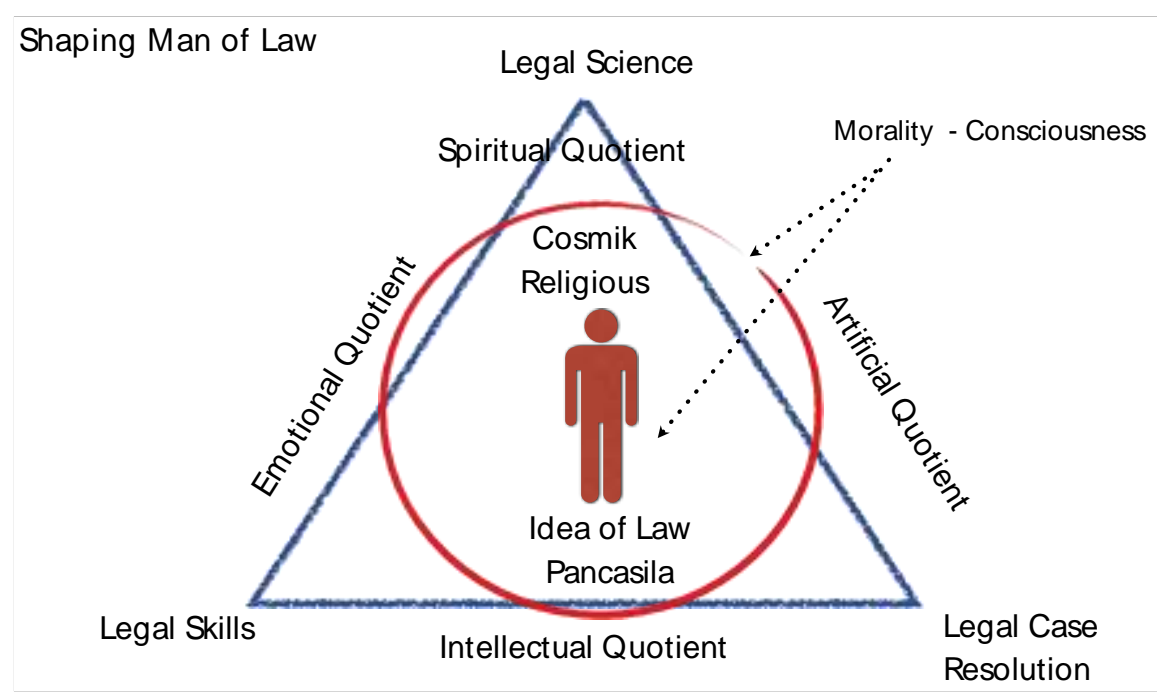

\section{Conclusion}

In the last part of this writing, it can be concluded that transgressive legal education is human education in the context of Indonesia with the soul of Pancasila. Transgressive legal education is an education to shape morality and consciousness to impose the law in the society as such they aware of the existence of the creator and are able to adapt it in law enforcement. Transgressive legal education, naturally, encourages the self-development of persons who are critical, tolerant, open, sensitive, and care about social problems and law enforcement. This education is none other than an education of behavior: moral and culture in the development of science, morality, and culture in the application of legal skills, morality and culture as the guidance to his own life. This can be achieved through the intelligence leap of IE, EQ, SQ, and AQ = IESAQ

\section{Bibliography}

Audrey R. Chapman, Sain Agama dan Lingkungan, in Audrey R. Chapman, Rodney L. Petersen, Barbara Smith Moran, Bumi yang terdesak, Mizan, Jakarta, 2007.

Audrey R. Chapman, Rodney L. Petersen, Barbara Smith Moran, Bumi yang terdesak, Mizan, Jakarta, 2007.

Agus Soedibyo, Jagat Digital; pembebasan dan Penguasaan, Kepustakaan Populer Gramedia - KPG, Jakarta, 2019.

Agus Nuryatno, Mazhab Pendidikan Kritis, Menyingkap Relasi Pengetahuan politik dan kekuasaan, Resist Book, Jakarta, 2008.

David Wallace Well, Bumi yang Tidak Dapat Dihuni, Kisah tentang Masa Depan, Gramedia Jakarta, 2019. 
Paul Davis, Tuhan, Dotrin dan Rasionalitas dalam debat sains modern, Fajar Pustaka Baru, Yogyakarta, 2002. , Mencari Tuhan dengan Fisika Baru, Nuansa Bandung, 2006.

Membaca Pikiran Tuhan, Dasar Dasar Ilmiah dalam Dunia yang Rasional, Pustaka Pelajar, Jogyakarta, 2012.

Fritjof Capra, The Hidden Connection, Strategi Sistemik melawan Kapitalisme Baru, Jalasutra, Bandung, 2009.

Fritjof Capra, Tao of Physics, Jalasutra, Yogyakarta, 2001.

2010.

Sains Leonardo, Menguak Kecerdasan terbesar masa Renaisans, Jalasutra, Yogyakarta,

Gary Zukaf, Makna Fisika Baru dalam Kehidupan, Kreasi Wacana, Yogyakarta, 2003

Bruce Lipton, The Biology Belief; Misteri Pikiran, keyakinan, sel dan DNA, Javanica, Tanggeran Selatan, 2019.

Gregg Braden, The Divine Matrix; Menyingkap Rahasia Alam semesta, Javanica, Tanggerang, 2018,

Ian Parson, You Tomorrow, Tentang Kita di Masa Depan, rene Book, Jakarta, 2019.

Onno W. Purbo, Filosofi Naif Kehidupan Dunia Cyber, Republika, Jakarta, 2003,

Carl Sagan, Kosmos, Kepustakaan Populer Gramedia,Jakarta, 2016.

Kishore Mahbubani, Asia Hemisfer Baru Dunia, Pergeseran Kekuatan Global ke Timur yang tak terelakan, Kompas, Jakarta, 2011.

Buletin Komisi Yudisial, Vol. VI. No.6. May- June 2012.

Simon Blackburn, Being Good, Pengantar Etika Praktis, Jendela Jogysakarta, 2004.

Gregory Leyh, Legal Hermeneutics, University of California Press, 1992.

James O freedman, Liberal Education and The Legal Profession, Southwestern Law Journal. 39, 1985.

Anthon F. Susanto, Dekonstruksi Hukum, Eksplorasi Teks dan Model Pembacaan, Genta Publishing, Jogyakarta, 2010,

Anthon F. Susanto, Hukum dari Consilience ke Paradigma Huku Konstruktif-Trangresif, Refika Aditama, Bandung, 2017.

Anthon F. Susanto, Penelitian Hukum Tranformatif-Paertisipatoris, Fubdasi Penelitian Kolaboratif dan Aplikasi Campuran dalam penelitian Hukum, Setara Press, Malang, 2015.

Alex Lanur, Dampak Konsep manusia Filsafat indonesia yang bersifat personalistic pada Pendidikan, in bunga rampai editor Sindunata, menggagas paradigma baru Pendidikan, Kanisius, Yogyakarta, 2000. 
Baharuddin \& Moh Makin, Pendidikan Humanistik (konsep, Teori dan Aplikasi Praksis dalam Dunia Pendidikan, Ar-Ruzz Media, Jogyakarta, 2011.

R.E. Elson, Yhe Idea of Indonesia, Sejarah Pemikiran dan Gagasan, Serambi, Jakarta, 2009.

Anthon F. Susanto, Filsafat dan Teori Hukum, Dinamika tafsir pemikiran di Indonesia, Prenadamedia, Bandung, 2019.

Jeffry L. Cruikshank, The Appel Way, 12 Pelajaran Managemen, Erlangga, 2008.

David A. Vise, Kisah Sukses Google, Gramedia, Jakarta 2006.

Jeff Zaleski, Spiritualitas Cyber space, MIzan, Bandung, 1999.

Mark Slouka's book, Ruang yang Hilang; Pandangan Humanis tentang Budaya Cyberspace yang merisaukan, Mizan, 1999.

Mochtar kusumaatmadja, Pendidikan Hukum Indoensia, explanation on 1993 curriculum Jurnal Hukum dan pembangunan, Nomor 6 Tahun 1994.

Mochtar Kusumaatmadja, Pembinaan Hukum dalam Rangka Pembangunan Nasional, Binacipta Jakarta, 1986.

Rhenald Kasali, Distruption, Gramedia, Jakarta, 2017.

Jamie Notter \& Maddie Grant, When Millenials Take Over, Elex Media Komputindo Kompas Gramedia Jakarta, 2018,

Yuswohady, Millenials Kill Everything, Gramedia Jakarta, 2019.

Alec Ross, The Industries of the Future, ReneBook, Jakarta, 2018.

Asa Briggs, \& Peter Burke, Sejarah Sosial Media, dari Gutenberg sampai Internet, Yayasan Obor Indonesia, 2006.

Nicholas A. Christakis, \& James H. Flower, Connected, Dahsyatnya Kekuatan jejaring Sosial mengubah Hidup kita, Gramedia Jakarta, 2010.

William F. O’neil, Idiologi Idiologi Pendidikan, Pustaka Pelajar, Jogyakarta, 2008.

Satjipto Rahardjo, Penegakan Hukum, suatu Tinjauan sosiologis, Genta Publishing, Yogyakarta, 2009.

Satjipto Rahardjo, Hukum dan Perilaku, Hidup yang baik adalah dasar hukum yang baik, Kompas, Jakarta, 2009.

Thomas Gray, Langdell's Orthodoxy; University Pittsburgh Law Review 45. 1985.

Robert B. Steven, Law School, Legal Education in America From the 1850s to be 1980s, Chape Hill; University of North Carolina Press, 1983. 
HAR Tilaar, Kekuasaan dan Pendidikan, manajemen Pendidikan Nasional dalam Pusaran Kekuasaan, Rineka Cipta, Jakarta, 2009.

Agus Nuryatno, Mazhab Pendidikan Kritis, Menyingkap Relasi Pengetahuan politik dan kekuasaan, Resist Book, Jakarta, 2008.

Paul Allman, Revolutionary Social Transformation, Democratic Hopes, Political Possibilities and Critical Education, Westport, CT and London; bergin \& gavery, 1998.

Satjiko Murata, The Tao of Islam, Kitab Rujukan tentang Relasi Gender dalam Kosmologi dan Teologi Islam, Mizan, Bandung, 1998.

Bruce Lipton, The Biology Belief; Misteri Pikiran, keyakinan, sel dan DNA, Javanica, Tanggeran Selatan, 2019.

Gregg Braden, The Divine Matrix; Menyingkap Rahasia Alam semesta, Javanica, Tanggerang, 2018.

Daniel Goleman, argued in his book of Working with Emotional Intelligence, Gramedia, Jakarta, 1999, Emotional Intelligence, Gramedia, Jakarta, 1993;

Danah Zohar dan Ian Marshall, SQ, Spriritual Intelligence; The Ultimate Intelligence, Bloomsbury, Great Britain, 2000,

Agus Efendi, Revolusi Kecerdasan abad 21, Alfabeta, Bandung, 2005.

Agus Nggermanto, Melejitkan IQ,EQ,SQ; Kecerdasan Quantum, Nuansa Cendikia, Bandung, 2015.

Howard, Gardner, Multiple Intelengences; Kecerdasan majemuk Teori dan Praktek, Interaksara, Batam, 2003.

Hamdani Bakran Adz-Dzakiey, Phrophetic Intelligence; Kecedasan Kenabian; Menumbuhkan potensi hakiki Insani, melalui Pengembangan Kesehatan Ruhani, Islamika, Jogyakarta, 2005.

\section{Copyrights}

Copyright for this article is retained by the author(s), with first publication rights granted to the journal.

This is an open-access article distributed under the terms and conditions of the Creative Commons Attribution license (http://creativecommons.org/licenses/by/4.0/). 